\title{
Utjecaj hormonskih tretiranja na zakorjenjivanje odrvenjelih reznica obične smreke (Picea abies /L./ Karsten)
}

\author{
Nikola Bursać, Ivica Čehulić, Mladen Ivanković, Saša Bogdan
}

\begin{abstract}
Nacrtak - Abstract
U Hrvatskoj je selekcijom plus stabala u jednoj matičnoj populaciji pokrenuto oplemenjivanje obične smreke kao božićnoga droca. Idući je cilj toga procesa utrđivanje optimalne procedure kloniranja izabranih plus stabala radi masovne proizvodnje reprodukcijskoga materijala (sadnica). Pretpostavka je da će se takvim načinom stvoriti kvalitetan reprodukcijski materijal koji će se odlikovati stabilnošću ciljnih fenotipskih svojstava. U radu su predstavljeni prvi rezultati istraživanja mogućnosti kloniranja plus stabala obične smreke metodom zakorjenjivanja odrvenjelih reznica.
\end{abstract}

Glavni cilj istraživanja bio je utvrđivanje uspješnosti primjene raznovrsnih hormonskih tretmana na zakorjenjivanje odrvenjelih reznica starijih (10-12 godina) stabala obične smreke uzetih $u$ ranoproljetnom i kasnojesenskom razdoblju s različitih visinskih etaža krošanja (gornja, srednja $i$ donja trećina krošnje). Provedena su dva eksperimenta. U prvom je po 270 reznica odrezano u rano proljeće iz svake od triju visinskih etaža krošanja, na uzorku od 10 stabala. Po 10 reznica iz svake etaže tretirano je s 27 različitih tretmana ( 2 tipa hormona $\times 4$ koncentracije otopine $\times 3$ vremena trajanja tretiranja + Clonex + kontrola $1+$ kontrola 2$)$. Drugo je istraživanje provedeno na po 80 reznica odrezanih iz donje trećine krošanja od 13 izabranih plus stabala u kasnu jesen. Po 30 reznica tretirano je u trajanju od 10 sekundi sa: (i) hormonom IBA koncentracije 2500 ppm, (ii) hormonom IBA koncentracije 500 ppm. Ostatak od 20 reznica poslužio je kao kontrola. Nakon tretiranja hormonom reznice su pikirane u tzv. "paper pot saća (sadrže 80 heksagonalnih otvora dubine $15 \mathrm{~cm}$, napunjenih supstratom treset : pijesak u omjeru $3: 1)$. U listopadu nakon pikiranja obavljena je determinacija uspješnosti zakorjenjivanja svake pojedine reznice, utvrdivanje broja korijenskih žila zakorijenjenih reznica te izmjere duljine najdulje razvijene korijenske žile na svakoj zakorijenjenoj reznici.

Rezultati su pokazali da se stabla obične smreke u dobi od desetak godina u prosjeku mogu relativno uspješno klonirati metodom zakorjenjivanja odrvenjelih reznica uzetih iz donje trećine krošanja u kasnu jesen ili rano proljeće, $i$ to bez ikakva tretiranja (50\%-tni uspjeh). Postotak zakorijenjenih reznica i kvaliteta novostvorenoga korijena mogu se poboljšati jeftinim, ali čini se učinkovitim tretiranjem baze reznica destiliranom vodom u trajanju od dva sata. Međutim, rezultati su pokazali da bi se tretiranjem baze odrvenjelih reznica uzetih u rano proljeće hormonskom otopinom IBA koncentracije 500 ppm u trajanju od 10 s postotak uspješnoga zakorjenjivanja mogao značajno povećati (u prosjeku do 80 \%-tne zakorijenjenosti). Odrvenjele reznice uzete iz donje trećine krošanja najbolje se zakorjenjuju, čak $i$ bez ikakvih tretiranja (50 \% kontrolnih reznica, u usporedbi s $40 \%$ kontrolnih reznica iz srednje i $20 \%$ zakorijenjenih kontrolnih reznica iz gornje trećine krošnje). Rezultati su otkrili izrazite individualne razlike u uspjehu zakorjenjivanja reznica uzetih iz donje etaže (postotak zakorjenjivanja kretao se od $0 \%$ do $100 \%$ ).

Ključne riječi: božićna drvca, oplemenjivanje, plus stabla, kloniranje, genotipovi, IBA, NAA. 


\section{Uvod - Introduction}

Naši uzgajivači (dobavljači) božićnih drvaca uglavnom ne raspolažu s genetski kvalitetnim, testiranim reprodukcijskim materijalom koji bi se odlikovao stabilnošću poželjnih fenotipskih svojstava, što, među ostalim, rezultira velikim varijacijama $u$ kvaliteti njihova konačnoga proizvoda.

U Hrvatskoj se za božićno ukrašavanje doma najviše koristi obična smreka ponajviše zbog dostupnosti i cjenovne povoljnosti. Prema dostupnim podacima godišnje se proizvede 500000 komada drvaca, a najviše u Koprivničko-križevačkoj, Bjelovarsko-bilogorskoj i Zagrebačkoj županiji. U usporedbi s ostalim, za tu svrhu korištenim vrstama drveća, božićna drvca obične smreke uglavnom su najnižega cjenovnoga razreda, a često se odlikuju manje atraktivnim fenotipskim obilježjima.

Da bi se podigla kvaliteta, isplativost i autohtonost proizvodnje obične smreke kao božićnoga drvca, skupina je entuzijasta odlučila pokrenuti proces oplemenjivanja radi masovnije proizvodnje njezina genetski oplemenjenoga reprodukcijskoga materijala (Bogdan i dr. 2017).

\subsection{Dosadašnje spoznaje o mogućnostima kloniranja obične smreke metodom zakorjenjivanja reznica - Recent knowledge on possibilities for Norway spruce cloning by rooting of cuttings}

S obzirom na dob matičnih biljaka većina autora smatra da se bolje zakorjenjuju reznice uzete sa što je moguće mlađih matičnih biljaka. OuYang i dr. (2014) uspješno masovno zakorjenjuju reznice uzete s petogodišnjih stabala. Toogood (1999) također preporučuje mlade biljke (mlađe od šest godina). Nikkanen i dr. (2012) istražuju matične biljke u dobi od 5 do 55 godina te izvješćuju kako postotak zakorjenjivanja reznica pada sa starošću matične biljke, iako je zabilježeno i izvrsno zakorjenjivanje reznica od pojedinih jedinki starijih od 40 godina. Mnogi autori (npr. Clair i dr. 1985, Dekker-Robertson i dr. 1991, Nikkanen i dr. 2012) preporučuju da se kod starijih (>5 god.) biljaka koriste metode rejuvenilizacije (npr. ponovljeno cijepljenje, serijska propagacija, živičnjak, zasjenjivanje) radi smanjenja efekta ciklofizisa.

S obzirom na vrijeme skupljanja reznica različiti autori daju vrlo različite preporuke. OuYang i dr. (2014) uzimali su reznice u svibnju (nove zelene reznice), ali preporučuju prethodno dva puta tjedno gnojenje matičnih biljaka. Međedović i Ferhato- vić (2003) preporučuju uzeti reznice krajem lipnja odnosno početkom srpnja. Toogood (1999) navodi srpanj/kolovoz ili veljaču/ožujak kao najbolje vrijeme. Nikkanen i dr. (2012) uzimali su reznice u prosincu/siječnju (odrezane grane stavili su u kutije sa snijegom i čuvali na $-5{ }^{\circ} \mathrm{C}$ do ožujka) ili u kolovozu (odrezane grane čuvali nekoliko dana u vlažnim uvjetima na $2-4{ }^{\circ} \mathrm{C}$ ). Međutim, priznaju da su sa zadnjim doživjeli katastrofalan neuspjeh. Farrar (1939), Oliver i Nelson (1957), prema Nikkanenu i dr. (2012), preporučuju prosinac, dok kolovoz odnosno rujan preporučuju Kelly (1972) te Iseli i Van Meter (1980), prema Nikkanenu i dr. (2012). S druge strane travanj/svibanj (neposredno prije ili za vrijeme otvaranja pupova) kao idealno vrijeme za uzimanje reznica preporučuje Girouard (1975), prema Nikkanenu i dr. (2012), te Fojtik (1982), prema Juraseku i J. Martincová (2004).

$S$ obzirom na položaj reznica na matičnoj biljci različiti autori također nemaju jedinstvene preporuke. Toogood (1999) izvješćuje da je najbolji uspjeh zakorjenjivanja kod reznica s vršnih izbojaka. S druge strane Oliver i Nelson (1957) te Ferguson (1968), prema Nikkanenu i dr. (2012), preporučuju uzimati reznice s postranih izbojaka. Girouard (1975), prema Nikkanenu i dr. (2012), nije dobio značajne razlike u zakorjenjivanju reznica između vršnih i postranih izbojaka. OuYang i dr. (2014) najbolje su zakorjenjivanje postigli s reznicama iz prvoga (donjega) pršljena grana. Nikkanen i dr. (2012) za stabla viša od $5 \mathrm{~m}$ preporučuju uzimati reznice iz druge gornje četvrtine krošnje, a kod nižih iz cijele krošnje. Jurásek i Martincová (2004), Roulund (1975) te Hannerz i dr. (1999), prema Nikkanenu i dr. (2012), izvješćuju da je reznicama uzetim s donjih pršljenova bolje zakorjenjivanje, ali upozoravaju i na veću vjerojatnost plagiotropnoga rasta kod takvih reznica. Slično kao i kod prethodnih autora, Olesen (1978), Kleinschmit i dr. (1973), Roulund (1975) i Pulkkinen (1992), prema Nikkanenu i dr. (2012), dobili su manje plagiotropnoga rasta kod zakorijenjenih reznica iz gornjih pršljenova, ali i njihovo slabije zakorjenjivanje u odnosu na reznice uzete iz donjega dijela krošnje (Jurásek i Martincová 2004). Hauck i Volná (1989, 1990), prema Juráseku i J. Martincová (2004), najbolje su zakorjenjivanje postigli kod reznica uzetih od 3. do 6. pršljena. I na kraju, Spethmann (1997), prema Juráseku i J. Martincová (2004), preporučuju uzimati reznice koje se nalaze bliže deblu, neovisno o pršljenu.

Što se tiče veličine reznica, OuYang i dr. (2014) postigli su najbolji uspjeh s 3-4 mm debelim i 9-12 $\mathrm{cm}$ dugim. Sitnije, ali i krupnije, $\mathrm{u}$ istom su istra- 
živanju pokazale slabije rezultate. Wühlisch (1984) preporučuje zelene i poluodrvenjele reznice rezane na $4 \mathrm{~cm}$, a odrvenjele na $10 \mathrm{~cm}$. Nikkanen i dr. (2012) predlažu reznice dulje od 5 (6) $\mathrm{cm}$ da bi se dobili najbolji rezultati zakorjenjivanja.

Hormonski tretman reznica preporučuju brojni autori, ali se njihovi rezultati značajno razlikuju $\mathrm{s}$ obzirom na tip, koncentraciju i vrijeme trajanja tretiranja hormonom. Međedović i Ferhatović (2003) izvješćuju da se najbolji rezultati postižu primjenom IAA koncentracije $50 \mathrm{mg} / \mathrm{l}$ (ne navode vrijeme trajanja tretiranja). OuYang i dr. (2014) najbolje su rezultate postigli tretiranjem reznica hormonom IBA (koncentracije $200 \mathrm{mg} / \mathrm{l}$ u trajanju $2 \mathrm{~h}$ ). Samo neznatno slabiji uspjeh isti su autori postigli i primjenom IBA (150 mg/l u trajanju 0,5 h). OuYang i dr. (2014) izvješćuju i o odličnom postotku zakorjenjivanja reznica tretiranih prahom ABT-1 $(100 \mathrm{mg} / \mathrm{l} \mathrm{u}$ trajanju od 1 h) te bez hormonskoga tretmana (reznice namočene $1 \mathrm{~h}$ u običnu vodu sa $150 \mathrm{ml} / 1$ destilirane vode. Međutim, unatoč visokomu postotku zakorjenjivanja parametri kvalitete korijena bili su značajno slabiji u usporedbi s tretmanima hormonom IBA. Ma i dr. (2011) dobili su odlične rezultate primjenom IBA (koncentracije 200 ppm u trajanju od 2 h). Mnogo više koncentracije hormona IBA (4 g/l) kao uzročnike najboljih rezultata zakorjenjivanja navodi Al-Kinany (1981), uz indicije da bi još viša koncentracija toga hormona dala čak i bolje rezultate. Neki autori navode kako se reznice obične smreke sasvim dobro zakorjenjuju i bez ikakva hormonskoga tretmana. Tako Jurásek i Martincová (2004) izvješćuju da je zakorjenjivanje netretiranih reznica više od $70 \%$. Wühlisch (1984) potvrđuje odlično zakorjenjivanje netretiranih reznica (reznice su umjesto hormonima tretirane fungicidnim sredstvom), ali upozorava da postotak zakorjenjivanja takvih reznica pada sa starošću - vrlo mlade sadnice $100 \%$ zakorjenjivanje, a 12-godišnje 50-75\%. Treba napomenuti da su neki autori izvijestili kako je hormonski tretman imao neutralan ili pak negativan utjecaj (Farrar 1939, Girouard 1973, Dirr i Heuser 2006, Teivonen 2010, prema Nikkanenu i dr. 2012).

Supstrat za zakorjenjivanje reznica dodatan je važan čimbenik za uspjeh zakorjenjivanja reznica obične smreke, ali i ovdje različiti autori imaju vrlo raznovrsne preporuke. OuYang i dr. (2014) najbolje su rezultate postigli mješavinom treseta i ljusaka riže u omjeru $1: 1$. Međedović i Ferhatović (2003) preporučuju supstrat pijesak : treset u omjeru $2: 1$. Isti supstrat, ali u omjeru 1: 1 preporučuju Ferguson (1968) i Girouard (1973), prema Nikkanenu i dr. (2012), dok taj supstrat u omjeru $60: 40$ preporučuju
Jurásek i Martincová (2004). Najbolje zakorjenjivanje supstratom napravljenim od perlita i pijeska u omjeru 1 : 1 postigao je Wühlisch (1984), ali samo kod reznica uzetih do studenoga. Za reznice uzete nakon studenoga isti je autor preporučio perlit : treset : pijesak (u omjeru 40 : 50 : 10). Nikkanen i dr. (2012) odlične su rezultate postigli supstratom napravljenim od vermikulita i treseta $(1: 1)$, ali navode da bi vjerojatno bilo još bolje upotrijebiti perlit i treset $\mathrm{u}$ istom omjeru. Girouard (1975) te Iseli i Van Meter (1980), prema Nikkanenu i dr. (2012), najbolje su rezultate postigli čistim perlitom kao supstratom za zakorjenjivanje, dok $100 \%$-tni vermikulit preporučuju Oliver i Nelson (1957) prema Nikkanenu i dr. (2012). Toogood (1999) naglašava da je izuzetno važno da baza reznice ima zraka (aerirana), stoga općenito preporučuje prozračan supstrat. Neki autori navode da se radi aeracije ne preporučuje bazu reznice očistiti od iglica (Toogood 1999, Nikkanen i dr. 2012).

I na kraju, različiti se autori bave i istraživanjem utjecaja različitih abiotskih tretmana reznica nakon pikiranja u supstrat. OuYang i dr. (2014) izdvojili su kao vrlo važno tretiranje reznica fungicidom (svakih 10 dana), a Nikkanen i dr. (2012) preporučuju isto svakih 14 dana. Folijarna prihrana svakih 14 dana značajno je unaprijedila zakorjenjivanje reznica i kvalitetu korijena (OuYang i dr. 2014). Održavanje visoke zračne vlage (70-95 \%) kao važan čimbenik uspjeha zakorjenjivanja reznica (zamagljivanjem ili pokrivanjem pvc folijom) navode OuYang i dr. (2014) i Wühlisch (1984). Toogood (1999) preporučuje grijanje supstrata za zimske reznice (na temperaturu 15-20 ${ }^{\circ} \mathrm{C}$ ), a Wühlisch (1984) stalno održavanje temperature zraka na $18-24{ }^{\circ} \mathrm{C}$. Izvrsne rezultate $\mathrm{u}$ zakorjenjivanju reznica obične smreke postigli su Nikkanen i dr. (2012) potpunom kontrolom okoliša nakon pikiranja (temperatura zraka $15{ }^{\circ} \mathrm{C}$, grijanje supstrata na $22{ }^{\circ} \mathrm{C}$, zračna vlaga $80-90 \%$, dodatno svjetlo $12 \mathrm{~h}$ dan).

Kao što se može vidjeti iz ovoga pregleda, autori koji su se bavili problematikom kloniranja obične smreke metodom zakorjenjivanja reznica, uglavnom izvješćuju o dobrim rezultatima, ali se najbolja tehnologija ne može nedvojbeno iščitati iz literaturnih podataka.

\section{Materijal i metode Material and methods}

Da bi se istražila uspješnost različitih kombinacija tretmana i identifikacije potencijalne tehnologije koja bi dala zadovoljavajuće rezultate $u$ našim uvjetima, nužno je bilo ispitati utjecaj ovih čimbenika na 
uspjeh zakorjenjivanja i kvalitetu sadnica u našim uvjetima:

$\Rightarrow$ vrijeme skupljanja reznica s matičnih stabala

$\Rightarrow$ položaj reznica na matičnom stablu (gornja, srednja ili donja etaža krošnje)

$\Rightarrow$ hormonski tretman reznica

- tip hormona

- koncentracija hormona

- vrijeme tretiranja baze reznica hormonom.

$S$ obzirom na ispitivanje nabrojenih čimbenika provedena su dva eksperimenta koji se opisuju u nastavku.

\subsection{Eksperiment 1 - Study 1}

U prvom eksperimentu pažnja je bila usmjerena na ispitivanje uspješnosti zakorjenjivanja s obzirom na trajanje hormonskoga tretiranja $(10 \mathrm{~s}, 1 \mathrm{~h}, 2 \mathrm{~h}) \mathrm{i}$ tip hormonskoga preparata, te na uspješnost zakorjenjivanja $s$ obzirom na položaj reznica $u$ etažama krošanja matičnih stabala (gornja, srednja ili donja trećina krošnje). Cilj je bio ispitati utjecaj položaja reznica u krošnji i vremenskoga tretiranja specifičnim koncentracijama i vrstama hormona.

\subsubsection{Postupci s reznicama-Procedures with cuttings}

U poljima Hrvatskoga šumarskoga instituta 1 . 4. 2015. godine odrezani su vršni dijelovi grana s 10 slučajno izabranih jedinki obične smreke u dobi oko 10 godina. Grane su odrezane po etažama (gornja, srednja i donja etaža, tj. gornja, srednja i donja trećina krošnje). Sa svake jedinke odrezano je prosječno šest grana po etaži. Grane su bile različite duljine i odrezane su oko cijeloga opsega krošnje, a imale su otprilike 5-7 jednogodišnjih izbojaka (najčešće jedan vršni i četiri do šest postranih). Odrezane su grane stavljene $u$ plastične vrećice koje su označene s obzirom na etažu. Grane su zatim tretirane fungicidom (Neoram WG / bakreni oksiklorid/ u koncentraciji $0,5 \%$ ) i pohranjene u hladnjaču $\mathrm{u}$ uvjetima temperature $3 \pm 2{ }^{\circ} \mathrm{C}$ i relativne vlage zraka od $60 \%$.

Dana 23. 4. 2015. grane su izvađene iz hladnjača te su s njih voćarskim škarama pod kutom od $45^{\circ}$ na bazi odrezane reznice (jednogodišnji postrani i vršni odrvenjeli izbojci). Rez je dodatno obrađen skalpelom, a baza reznice nije ozljeđivana (nije skinuta kora) i nisu skidane iglice. Reznice su pomiješane $s$ obzirom na matično stablo, ali se dobro pazilo da se ne pomiješaju s obzirom na etažu.
Reznice su tretirane otopinama hormona iz grupe auksina (biljnih hormona rasta), i to: IBA (indol maslačna kiselina) i NAA (naftiloctena kiselina) koje su pripremljene u različitim koncentracijama (5000, 2500, 500 i $250 \mathrm{ppm}$ ) otapanjem u $\mathrm{NaOH}$ i razrjeđivanjem destiliranom vodom. Tako pripremljenim hormonskim otopinama reznice su tretirane (umakanjem baze reznice $\mathrm{u}$ otopinu) prije pikiranja u supstrat, i to različitim vremenom trajanja tretiranja $(10 \mathrm{~s}$, $1 \mathrm{~h}$ i $2 \mathrm{~h}$ ). Osim opisanoga hormonskoga tretiranja dio je reznica tretiran komercijalnim hormonskim preparatom Clonex (to je sredstvo u obliku gela u kojega su baze reznica umočene), a dio nije tretiran hormonima (kontrola), i to: kontrola 1 (potpuni izostanak bilo kakva tretmana, reznice su odmah pikirane u supstrat) i kontrola 2 (baza je reznica prije pikiranja umočena $\mathrm{u}$ destiliranu vodu u trajanju od $2 \mathrm{~h}$ ).

Ukupno je bilo 27 kombinacija tretiranja (2 tipa hormona $\times 4$ koncentracije otopine $\times 3$ vremena trajanja tretiranja + Clonex + kontrola 1 + kontrola 2), a u svakoj je kombinaciji tretirano 10 reznica. Dakle, na različite je načine tretirano (ili netretirano) ukupno 270 reznica iz svake etaže odnosno ukupno 810 reznica (270 reznica $\times 3$ etaže krošnje).

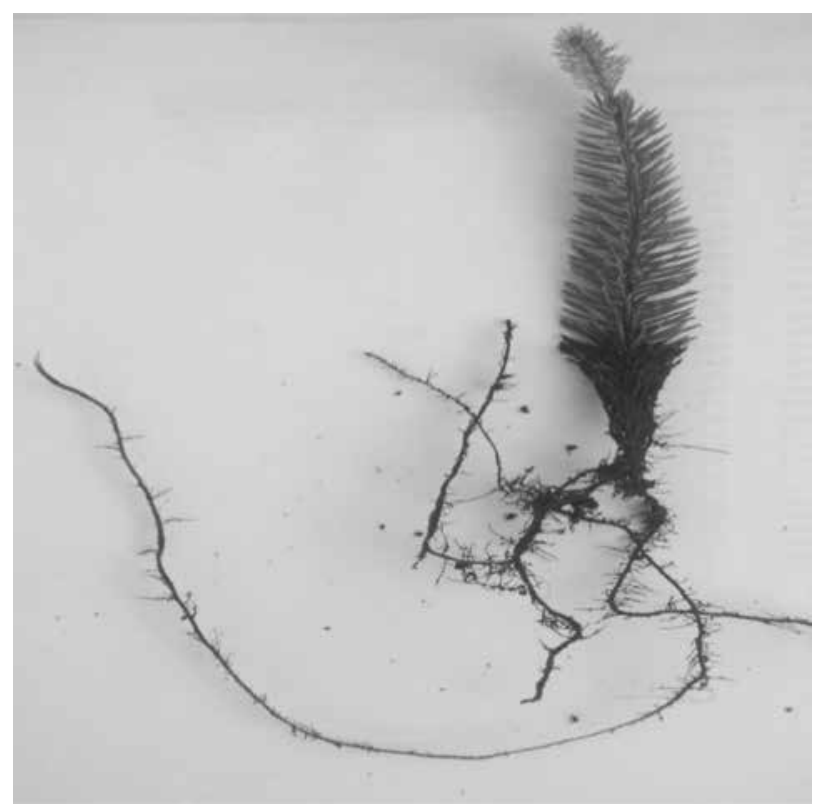

Slika 1. Zakorijenjena reznica obične smreke

Fig. 1 Rooted cutting of Norway spruce

Reznice su pikirane $\mathrm{u}$ kontejnere Bosnaplast punjene supstratom treset : perlit $u$ omjeru $56: 44 \%$ (250 L treseta i $200 \mathrm{~L}$ perlita). Kontejneri s reznicama zatim su pohranjeni na stolove $\mathrm{u}$ plastenik na zakorjenjivanje. Grijanjem stolova održavala se temperatura supstrata na $20^{\circ} \mathrm{C}$, a sustavom automatskoga 
zamagljivanja održavala se zračna vlaga na min. 80 $\%$. Reznice su također na dan pikiranja tretirane fungicidnim zaštitnim sredstvom Astor s aktivnom tvari Kaptan $50 \%$, u koncentraciji od 0,3\% na 20 $\mathrm{L}$ vode. U listopadu 2015. godine obavljeno je vađenje reznica iz kontejnera, determinacija uspješnosti zakorjenjivanja svake pojedine reznice, utvrđivanje broja korijenskih žila zakorijenjenih reznica te izmjera duljine najdulje razvijene korijenske žile na svakoj zakorijenjenoj reznici (slika 1).

\subsection{Eksperiment 2 - Study 2}

Za drugi su eksperiment 2. 12. 2015. odrezani vršni dijelovi grana samo iz donje trećine krošnje na 13 izabranih plus stabala u Rasadniku Instituta. Razlog je tomu što su rezultati eksperimenta 1 (kao i literaturni podaci) ukazivali na bolje zakorjenjivanje reznica uzetih iz donje trećine krošanja, a želja je bila što prije započeti $s$ testiranjem uspješnosti kloniranja selektiranih plus jedinki. S uzorkovanih grana potom su odrezani jednogodišnji izbojci ( 80 reznica po stablu). Reznice su tretirane različitim koncentracijama hormona IBA s vremenom trajanja tretiranja od 10 sekundi:

$\Rightarrow$ IBA 2500 ppm - 30 reznica

$\Rightarrow$ IBA 500 ppm - 30 reznica

$\Rightarrow$ netretirano (kontrola) - 20 reznica.

Razlog zašto je u eksperimentu 2 korišten samo hormon IBA u navedenim koncentracijama i vremenu trajanja tretiranja i ovaj put leži u preliminarnim rezultatima eksperimenta 1 . Nakon tretiranja hormonom reznice su pikirane $\mathrm{u}$ tzv. paper pot saća (sadrže 80 heksagonalnih otvora dubine $15 \mathrm{~cm}$, napunjenih susptratom treset : pijesak u omjeru $3: 1$ ). Saća su etiketirana i stavljena u plastenik. Zračna se vlaga automatskim orošavanjem održavala na $70 \%$, a grijanje se supstrata održavalo na $22^{\circ} \mathrm{C}$.

Reznice su nakon završetka eksperimenta (u listopadu 2016. godine) pažljivo izvađene iz supstrata za zakorjenjivanje. Nakon toga je svakoj reznici vizualno utvrđeno je li se zakorijenila, a ako jest, onda su joj izbrojene korijenske žile i mjernom vrpcom izmjerena duljina najdulje korijenske žile (slika 1).

\subsection{Statistička obrada podataka - Statistical analyses}

Podaci dobiveni opisanim izmjerama obrađeni su deskriptivnom statističkom analizom u programu MS Excell 2016 radi utvrđivanja aritmetičkih srednjih vrijednosti za mjerena svojstva po različitim tretiranjima i s obzirom na istraživane čimbe- nike (mjesto uzimanja reznica, vrijeme uzimanja reznica, hormonski tretman, genotip).

\section{Rezultati - Results}

\subsection{Eksperiment 1 - Study 1}

3.1.1 Rezultati s obzirom na hormonske tretmane baze reznica iz gornje etaže krošanja - Results due to hormonal treatments of cuttings taken from upper part of crowns

Budući da reznice koje pripadaju kontroli 1 nisu tretirane ni s čim, onda je jasno da se uspješnost pojedinih tretmana na zakorjenjivanje reznica i na kvalitativna svojstva korijena (broj žila i najveća duljina korijena) može jasno uvidjeti njihovom usporedbom s rezultatima kontrole 1 . Također, usporedbama uspjeha zakorjenjivanja reznica iz kontrole 1 koje potječu iz različitih etaža matičnih stabala, može se uvidjeti koji su dijelovi krošnje pogodniji za uzimanje reznica.

Podaci o postotku zakorijenjenosti reznica iz gornje etaže po tretmanima (slika 2) prikazuju da je najveća zakorijenjenost bila ostvarena u kontroli 2 (baza reznica umočena $u$ destiliranu vodu u trajanju od 2 sata) s $50 \%$-tnom zakorijenjenošću. Vidljivo je da je tretiranje reznica samo destiliranom vodom blagotvorno djelovalo na njihovo zakorjenjivanje. Svi su hormonski tretmani velikom većinom pokazali negativno djelovanje na uspjeh zakorjenjivanja reznica, dok je tretman s IBA u koncentraciji 5000 ppm u trajanju od $2 \mathrm{~h}$ bio neutralan $\mathrm{u}$ odnosu na kontrolu 1 (koja je pokazala je $20 \%$-tnu zakorijenjenost reznica iz gornja etaže).

Prosjek broja korijenskih žila po tretmanima kod reznica iz gornje etaže prikazan je na slici 3 . Uočava se da je pozitivan utjecaj na povećanje broja korijenskih žila imalo tretiranje reznica destiliranom vodom (kontrola 2), tretiranje hormonom NAA u koncentraciji 250 ppm i trajanju od $10 \mathrm{~s}$, zatim tretiranje s IBA u koncentraciji $5000 \mathrm{ppm} u$ trajanju od $1 \mathrm{~h}$ i tretiranje istom otopinom, ali u kraćem trajanju (10 s) koje je pokazalo najveći utjecaj na povećanje broja korijenskih žila.

Na slici 4 vidljivo je da je pozitivan utjecaj na duljinu korijena jedino pokazao tretman hormonom NAA koncentracije $250 \mathrm{ppm}$ u trajanju od $10 \mathrm{~s}$. Svi su ostali tretmani pokazali negativan utjecaj na to svojstvo. Međutim, potrebno je naglasiti da su svi hormonski tretmani koji su pokazali pozitivan utjecaj na kvalitativna svojstva novostvorenoga korijena istodobno imali negativan utjecaj na uspjeh zakorjenjivanja. Stoga se ne može govoriti o pozitivnom 


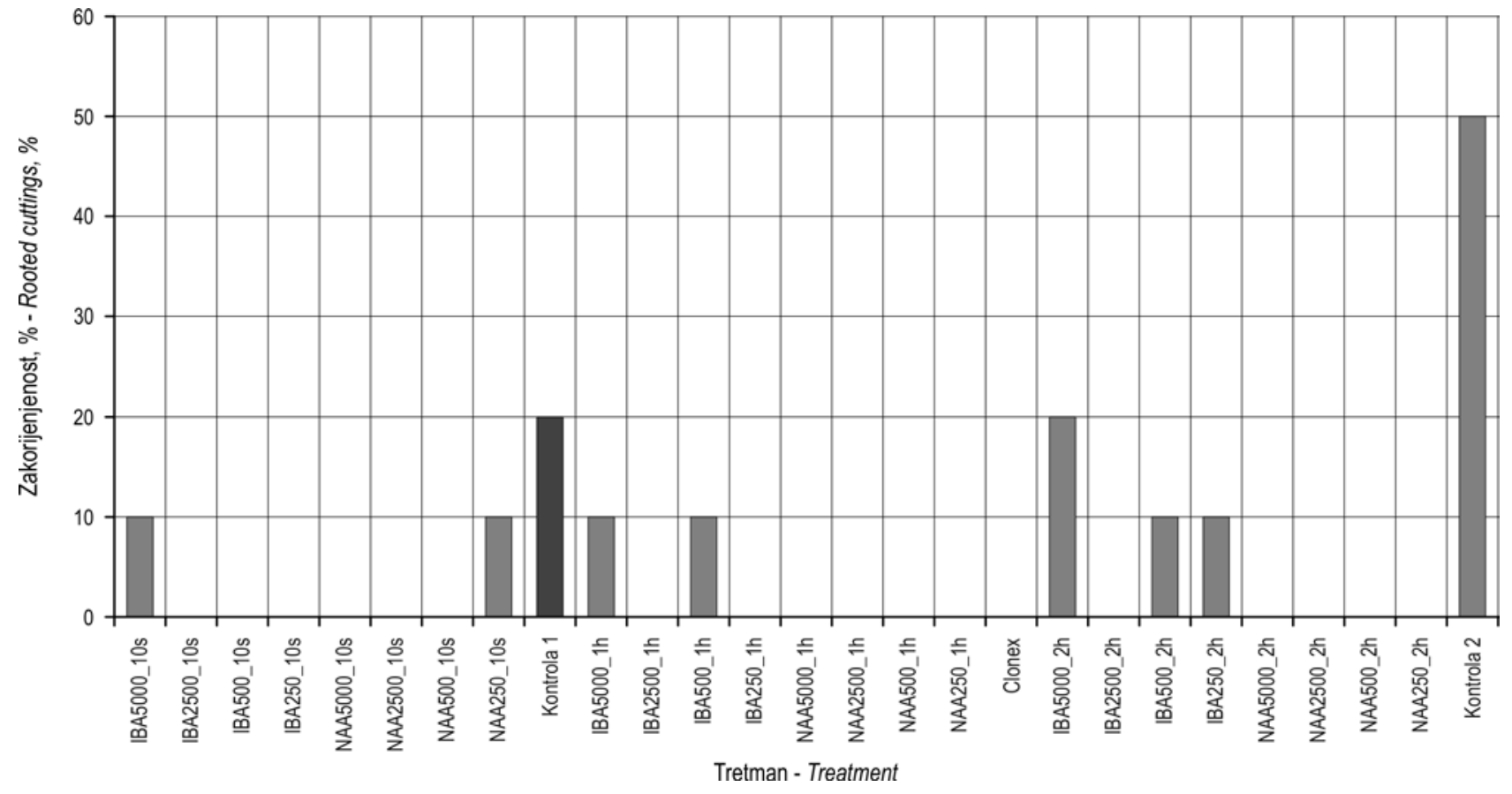

Slika 2. Postotak zakorijenjenih reznica iz gornje etaže s obzirom na hormonsko tretiranje

Fig. 2 Percentage of rooted cuttings taken from the upper third of crowns, due to hormonal tretaments

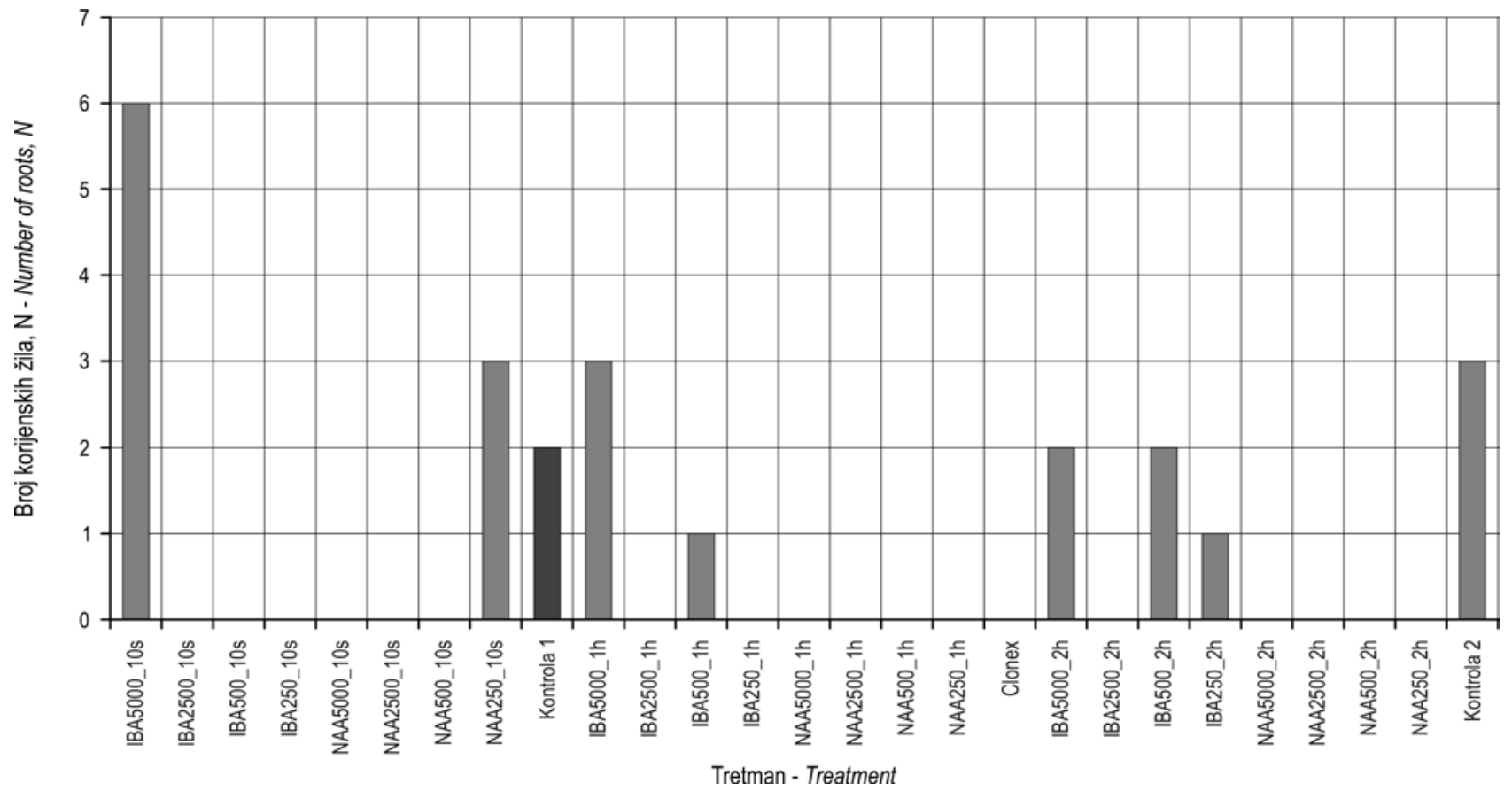

Slika 3. Prosječan broj korijenskih žila reznica iz gornje etaže po tretmanima

Fig. 3. Mean number of roots per cutting taken from the upper third of crowns, due to hormonal treatments 


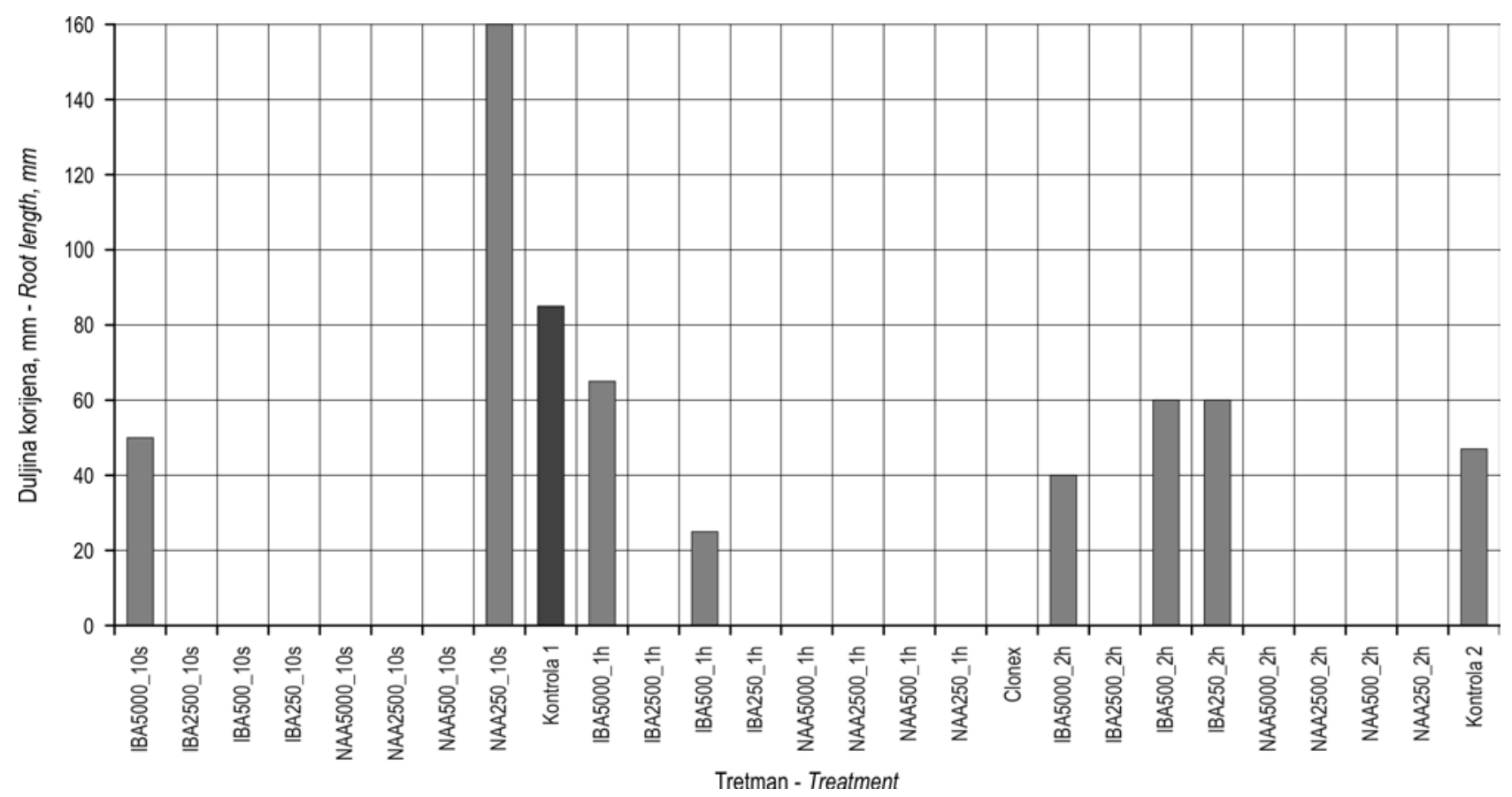

Slika 4. Prosječna duljina korijena reznica iz gornje etaže krošnje s obzirom na tretmane

Fig. 4. Mean root length per cutting taken from the upper third of crowns, due to hormonal treatments

utjecaju tretiranja reznica iz gornje etaže hormonskim otopinama. Jedini pravi pozitivan utjecaj imala je kontrola 2, tj. tretiranje baze reznica destiliranom vodom u trajanju od $2 \mathrm{~h}$ prije pikiranja, što je značajno povećalo postotak zakorijenjenosti, ali i poboljšalo razvijenost korijena kod reznica iz gornje etaže.

\subsubsection{Rezultati s obzirom na hormonske tretmane baze reznica iz srednje etaže krošanja - Results due to hormonal treatments of cuttings from middle part of crowns}

Promatrajući sliku 5 i uspoređujući ju sa slikom 2, može se uvidjeti da je uspjeh zakorjenjivanja reznica koje su uzete iz srednje etaže (srednja trećina krošnje) bio povećan u odnosu na gornju etažu. Naime, postotak zakorijenjenih reznica u kontroli 1 (netretirane reznice) porastao je s $20 \%$ na $40 \%$.

I kod te se etaže može vidjeti da je tretiranje baze reznica samo destiliranom vodom pozitivno djelovalo na uspjeh zakorjenjivanja (10\%-tno povećanje). Prema rezultatima ovoga istraživanja može se zaključiti da se tretiranjem baze reznica destiliranom vodom $\mathrm{u}$ trajanju od $2 \mathrm{~h}$ povećava postotak zakorijenjenih reznica uzetih iz gornje i srednje etaže (do maksimalnih $50 \%$ ).

Hormonski tretman baze reznica uzetih iz srednje trećine krošnje prije pikiranja uglavnom je ne- gativno utjecao na uspjeh njihova zakorjenjivanja. Međutim, tretman hormonskom otopinom IBA koncentracije 500 ppm u trajanju od $10 \mathrm{~s}$ značajno je povećao postotak zakorjenjivanja reznica u usporedbi s kontrolom 1 (za $20 \%$ ). Stoga se to tretiranje može preporučiti radi značajnijega povećanja postotka zakorijenjenih reznica uzetih iz srednje etaže (barem kod dormantnih reznica uzetih $\mathrm{u}$ ranoproljetnom razdoblju).

Na kvalitativna svojstva korijena (broj žila) kod zakorijenjenih reznica uzetih iz srednje etaže pozitivno je utjecalo nekoliko različitih tretmana hormonskim otopinama (slika 6). Međutim, pozornost zaslužuje isključivo tretman baze reznica destiliranom vodom (kontrola 2), jer je samo taj »tretman« ujedno pozitvno utjecao na povećanje postotka zakorijenjenih reznica. Zbog toga se hormonska tretiranja baze reznica uzetih iz srednje etaže krošnje koja su pozitivno utjecala na povećanje broja korijenskih žila ne mogu preporučiti (to su bili: IBA 5000 ppm_10 s, NAA 250 ppm_10 s, IBA 250 ppm_1 h, Clonex, IBA 5000 ppm_2 h).

Slično kao i kod broja korijenskih žila, tako je i kod maksimalne duljine korijena zabilježen veći ili manji pozitivan utjecaj različitih kombinacija hormonskoga tretmana baze reznica prije pikiranja (slika 7). Naravno, i kod toga svojstva većina nao- 


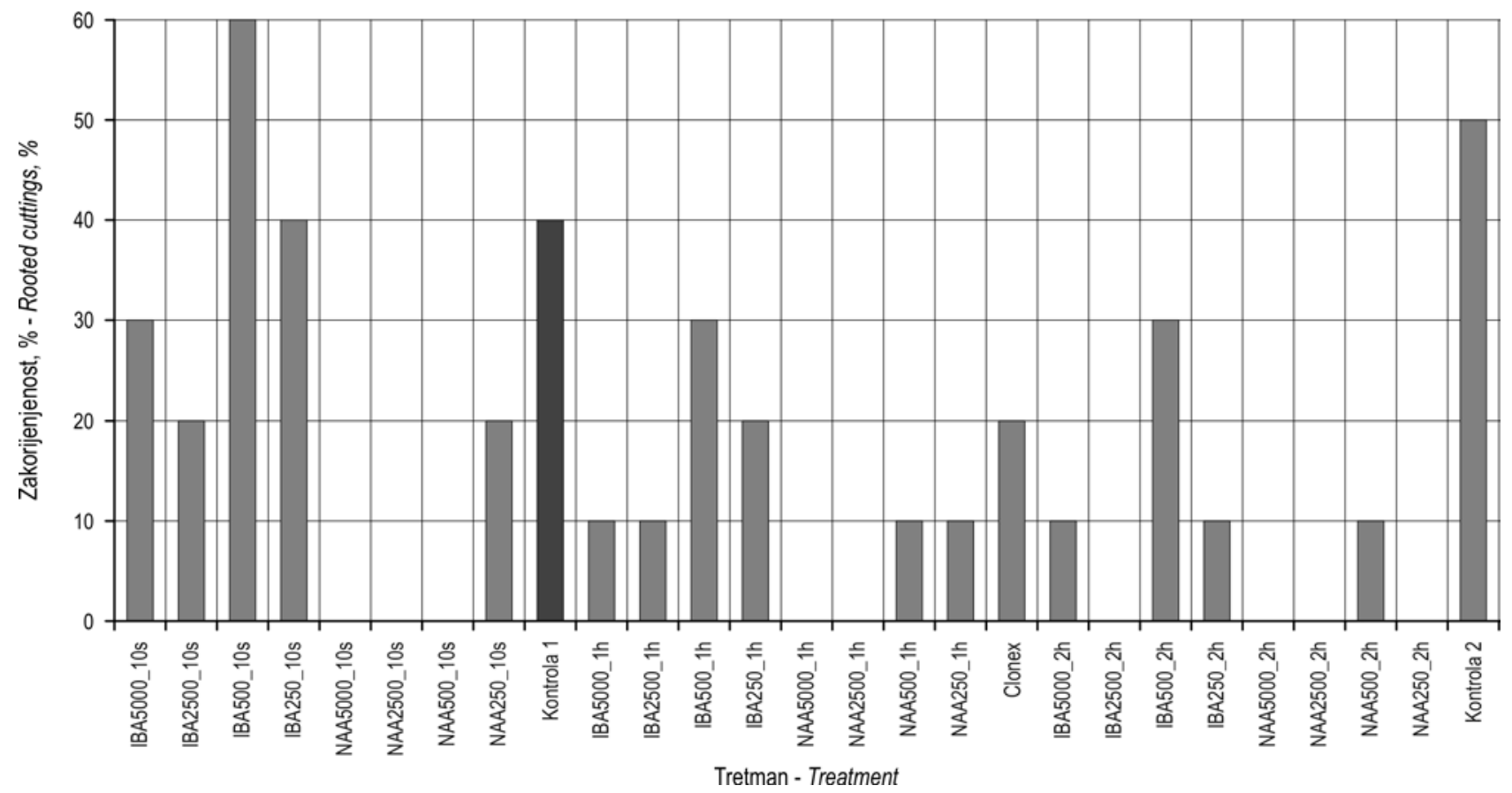

Slika 5. Postotak zakorijenjenih reznica iz srednje etaže krošanja s obzirom na hormonska tretiranja

Fig. 5 Percentage of rooted cuttings taken from the midle third of crowns, due to hormonal tretaments

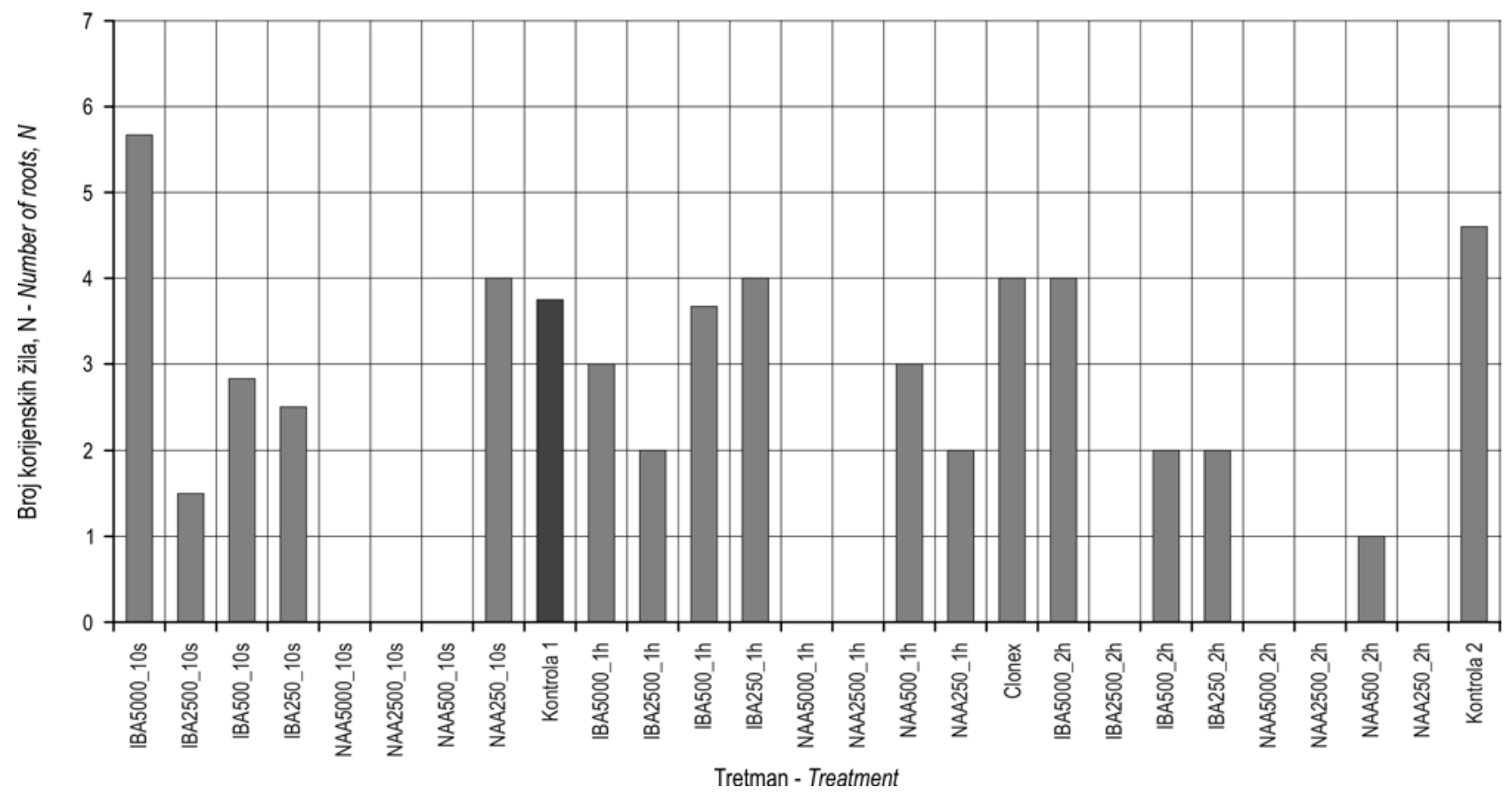

Slika 6. Prosječan broj korijenskih žila reznica iz srednje etaže krošanja po tretmanima

Fig. 6 Mean number of roots per cutting taken from the midle third of crowns, due to hormonal treatments

ko pozitivnih hormonskih tretmana ne zaslužuje pozornost jer su istodobno pokazala neutralan ili negativan utjecaj na uspjeh zakorjenjivanja reznica. Međutim, ovdje rezultati pokazuju da se radi postizanja bolje kvalitete korijena može preporučiti tretiranje baze reznica hormonskom otopinom IBA koncentracije $500 \mathrm{ppm} \mathrm{u}$ trajanju od $10 \mathrm{~s}$ te tretiranje destiliranom vodom $\mathrm{u}$ trajanju od $2 \mathrm{~h}$ prije pikiranja. 


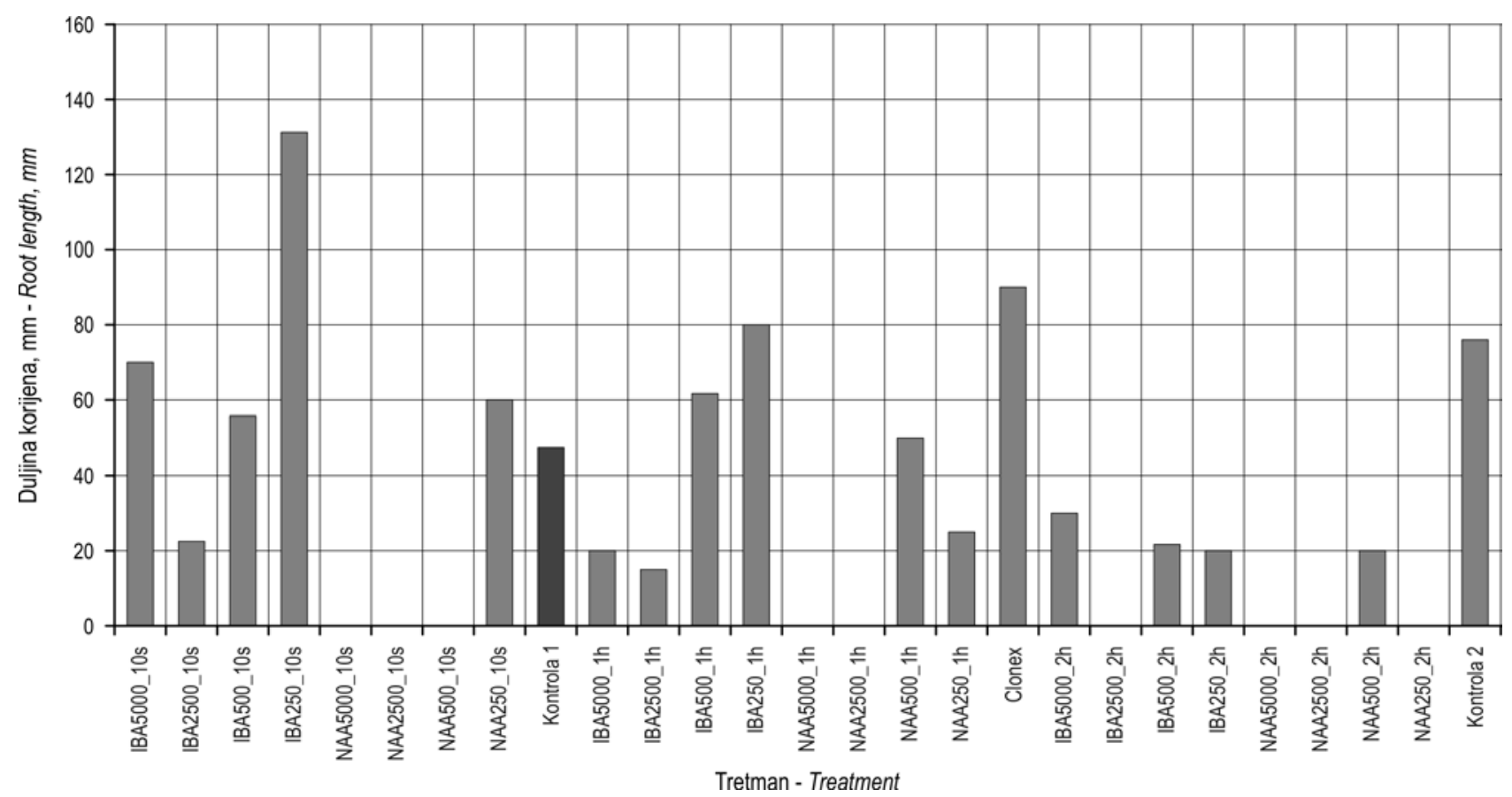

Slika 7. Prosječna duljina korijena reznica iz srednje etaže krošnje s obzirom na tretmane

Fig. 7 Mean root length per cutting taken from the midle third of crowns, due to hormonal treatments

Naime, oba su ta tretiranja ujedno i povećala postotak zakorijenjenih reznica iz srednje etaže (v. slika 5).

\subsubsection{Rezultati s obzirom na hormonske tretmane} baze reznica iz donje etaže krošanja - Results due to hormonal treatments of cuttings from lower part of crowns

Promatrajući sliku 8 i uspoređujući ju sa slikama 2 i 5 , razvidno je da su reznice matičnih stabala obične smreke $u$ dobi od 10 godina, uzete iz donje trećine krošanja, pokazale najveći uspjeh u zakorjenjivanju. To je jasno ako se usporede postoci zakorijenjenih reznica kontrole 1 na tri navedena grafikona. Naime, taj je postotak kod reznica uzetih iz gornje etaže iznosio $20 \%$, kod reznica uzetih iz srednje etaže bio je $40 \%$, a $50 \%$ kod reznica uzetih iz donje etaže.

Najveći pozitivan utjecaj na bolje zakorjenjivanje imao je tretman baze reznica hormonskom otopinom IBA koncentracije $500 \mathrm{ppm}$ u trajanju od $10 \mathrm{~s}$ prije pikiranja (povećanje za $30 \%$ ). Nakon te kombinacije slijedi tretiranje otopinom IBA koncentracije 250 ppm u trajanju od $10 \mathrm{~s}$ (povećanje za $20 \%$ ). I na kraju se s pozitivnim efektom na uspjeh zakorjenjivanja reznica uzetih iz donje etaže mogu izdvojiti i tretmani otopinom koncentracije IBA 500 ppm i koncentracije $250 \mathrm{ppm}$ u trajanju od $2 \mathrm{~h}$ prije pikiranja te tretiranje komercijalnim preparatom Clonex. Međutim, posljednji tretmani, iako su pokazali po- zitivan efekt, nisu bili nimalo »uspješniji« od tretiranja baze reznica destiliranom vodom (kontrola 2 ).

Promatrajući utjecaje hormonskih tretmana na povećanje broja korijenskih žila (slika 9), razvidno je da je više različitih kombinacija pozitivno utjecalo na to kvalitativno svojstvo. Međutim, izdvajaju se samo ona tretiranja koja su istodobno utjecala i na povećanje postotka zakorijenjenih reznica.

$S$ obzirom na to vrijedni su pozornosti tretmani: IBA 500 ppm_10 s, IBA 500 ppm_2 h, Clonex i destilirana voda_2 h (kontrola 2). Budući da je tretman s IBA 500 ppm_10 s imao najveći pozitivni efekt na uspjeh zakorjenjivanja (s $50 \%$ na $80 \%$ ), a pozitivno je utjecao i na povećanje broja korijenskih žila (s 2,8 na 3,4), onda se upravo taj tretman najviše može preporučiti za tretiranje reznica uzetih iz donje etaže.

$\mathrm{Na}$ drugom je mjestu pozitivnih tretmana IBA $500 \_2 \mathrm{~h}$, jer je postigao $10 \%$-tno povećanje postotka zakorijenjenosti reznica $u$ odnosu na kontrolu 1 (s $50 \%$ na $60 \%$ ), a istodobno je i značajno pozitivno utjecao na povećanje broja korijenskih žila kod zakorijenjenih reznica (povećanje s prosječnih 2,8 žila u kontroli 1 do prosječnih 4,5 žila).

Ne bi trebalo izostaviti ni tretman preparatom Clonex, čiji je efekt povećanja prosječnoga broja žila na 4,2, ali ni pozitivan efekt tretmana destiliranom vodom (»kontrola 2 «s prosječnim brojem žila 3 ). 


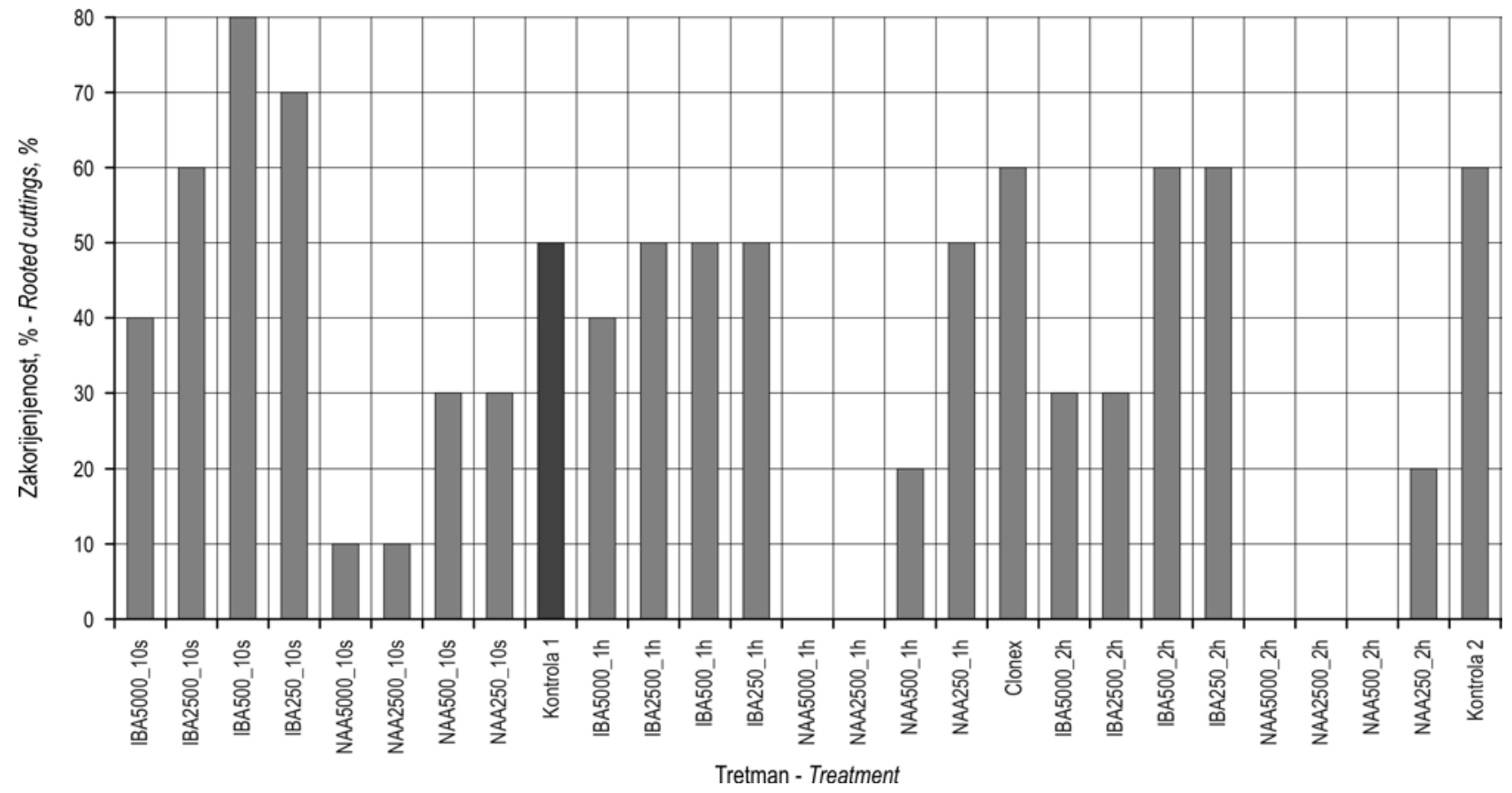

Slika 8. Postotak zakorijenjenih reznica iz donje etaže krošanja s obzirom na hormonska tretiranja Fig. 8 Percentage of rooted cuttings taken from the lower third of crowns, due to hormonal tretaments

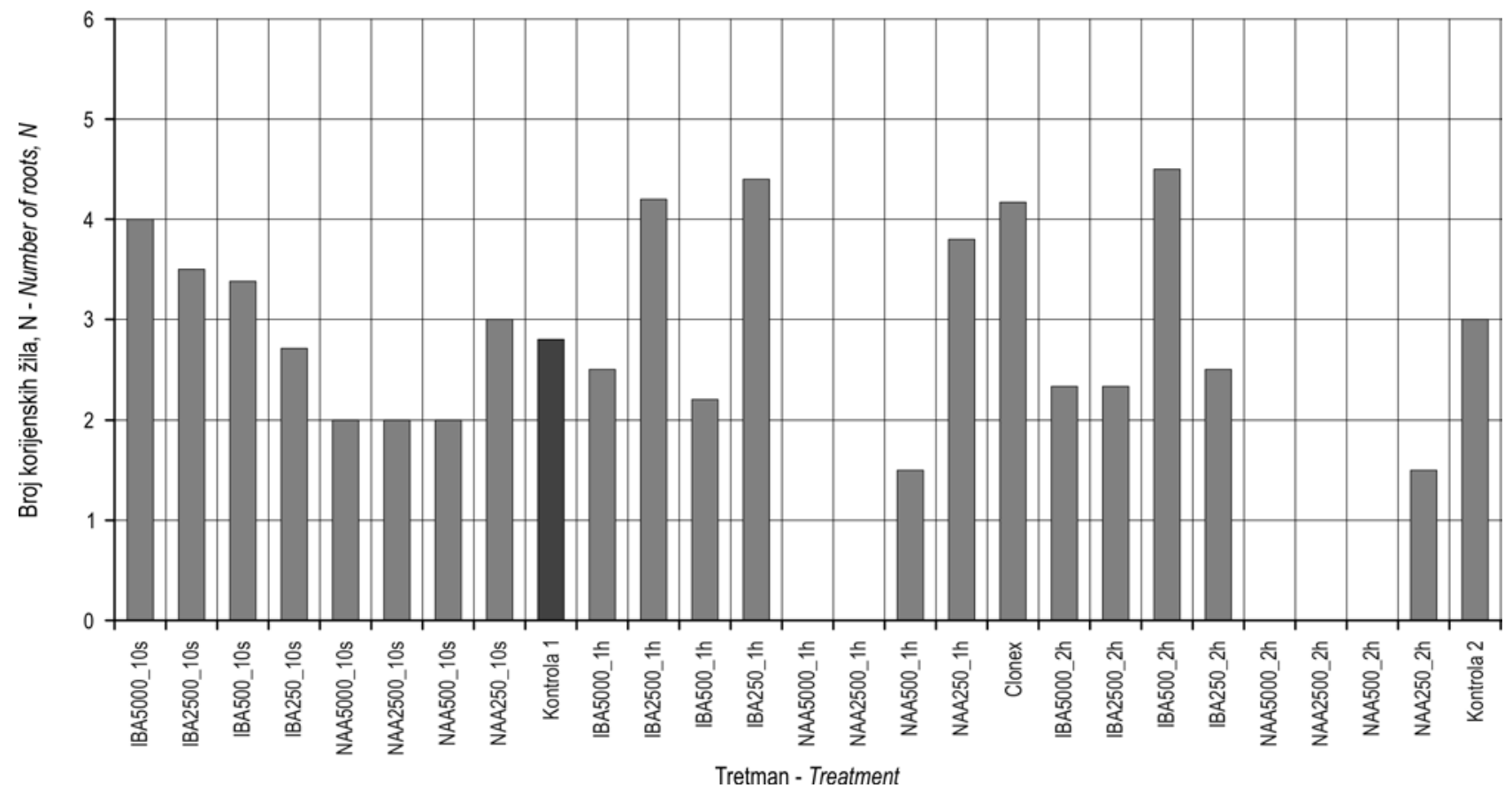

Slika 9. Prosječan broj korijenskih žila reznica iz donje etaže krošanja po tretmanima

Fig. 9 Mean number of roots per cutting taken from the lower third of crowns, due to hormonal treatments

Na povećanje maksimalne duljine korijena zakorijenjenih reznica pozitivno su utjecali tretmani raznovrsnim hormonskim otopinama odnosno trajanjem (slika 10), ali su vrijedni pozornosti samo oni koji su ujedno i utjecali na povećanje postotka zakorijenjenih reznica.

S obzirom na to mogu se izdvojiti tretmani oto- 


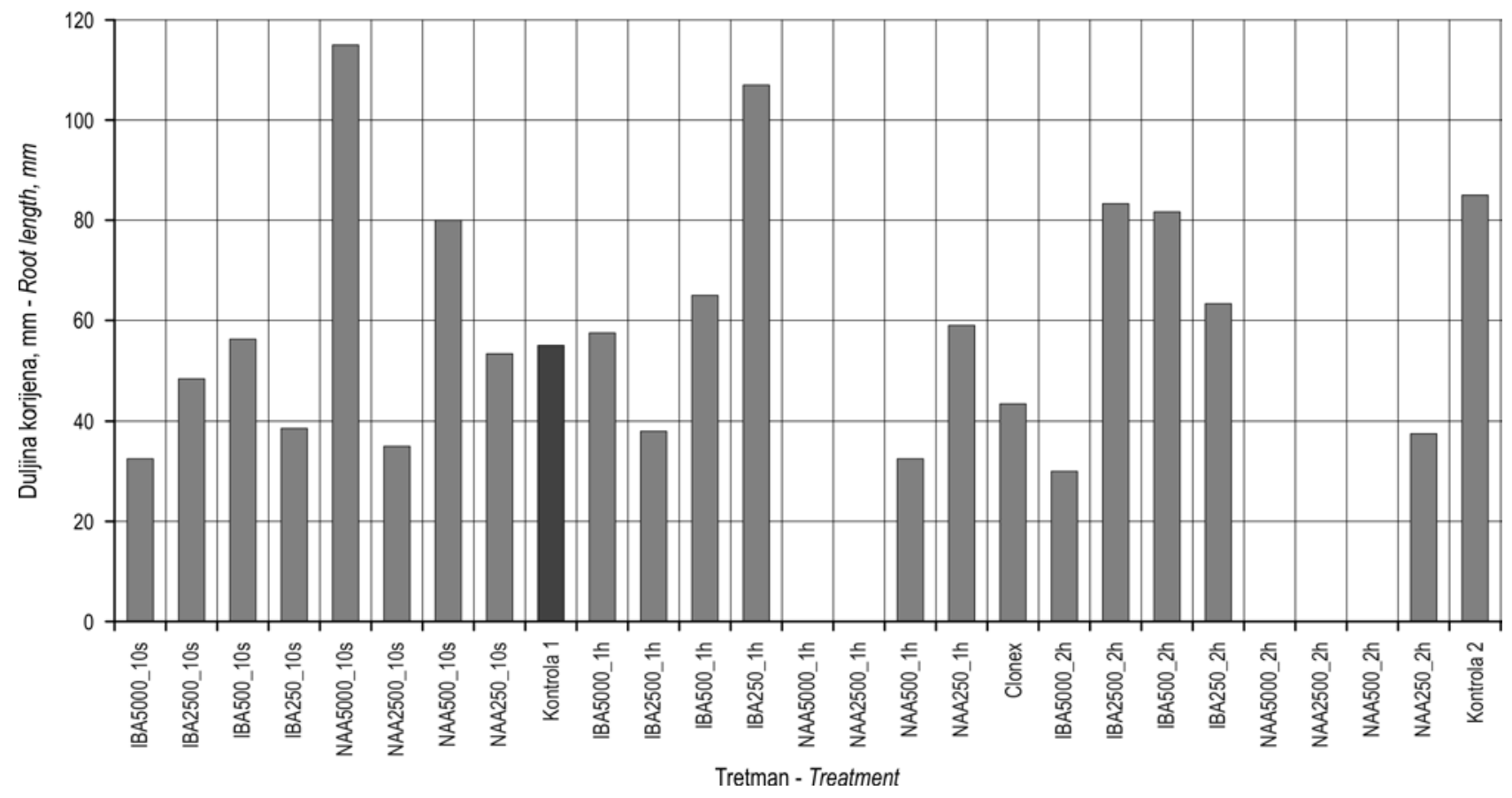

Slika 10. Prosječna duljina korijena reznica iz donje etaže krošnje s obzirom na tretmane

Fig. 10 Mean root length per cutting taken from the lower third of crowns, due to hormonal treatments

pinom IBA koncentracije 500 i 250 ppm u trajanju od $2 \mathrm{~h}$ te kontrola 2 odnosno tretiranje baze reznica destiliranom vodom.

\subsection{Eksperiment 2 - Study 2}

Sve reznice iz ovoga dijela istraživanja skupljene su u prosincu iz donje etaže plus stabala obične smreke. Reznice su tretirane različitim tipovima i koncentracijama hormona $\mathrm{u}$ trajanju od 10 sekundi.

\subsubsection{Uspješnost zakorjenjivanja reznica $s$} obzirom na genotip i tip hormonskoga tretiranja Rooting success due to genotype and hormonal treatment

U drugom se eksperimentu reznice, uzete iz donjih etaža izabranih plus stabala, tretiralo dvjema različitim koncentracijama hormona IBA (s 500 ppm i $2500 \mathrm{ppm}$ ). Vrijeme trajanja tretiranja baze reznica hormonskom otopinom iznosilo je 10 sekundi. Kao i u prvom istraživanju, pratio se utjecaj tretiranja reznica hormonskim otopinama na postotak zakorijenjenosti reznica i kvalitativna svojstva korijena (broj korijenskih žila i duljina najdulje žile korijena), ali u ovom je istraživanju bilo moguće istražiti međugenotipske varijacije. Također, potrebno je naglasiti da su u eksperimentu 2 reznice s matičnih stabala uzete u kasnojesenskom razdoblju (početak prosinca), dok su u eksperimentu 1 reznice uzimane $u$ ranoproljetno vrijeme (početak travnja). To je važno zapamtiti radi usporedbe rezultata tih dvaju eksperimenata.

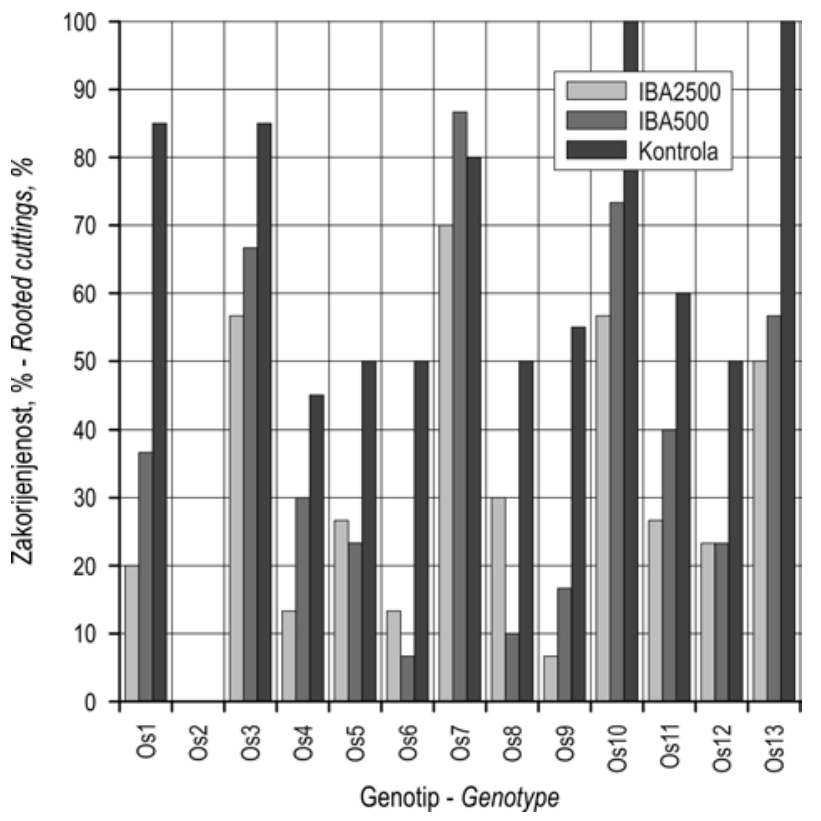

Slika 11. Usporedba postotka zakorijenjenosti po genotipovima s obzirom na tretiranja

Fig. 11 Percentage of rooting cuttings due to various genotypes and hormonal treatments 
Iz slike 11 vidljivo je kako su se reznice svih genotipova (plus jedinki) izuzev OS 2 prilično dobro zakorijenile bez ikakva tretiranja (kontrola). Postotak zakorijenjenosti kontrolnih reznica po genotipovima kretao se od najnižega $45 \%$ (OS 4) do $100 \%$ (OS 10 i OS 13). Dakle, ti rezultati upućuju na značajnu varijabilnost zakorjenjivanja reznica s obzirom na genotip.

Jasno je vidljivo da je tretiranje baze reznica hormonskim otopinama IBA prije pikiranja uglavnom negativno djelovalo na uspješnost njihova zakorjenjivanja. Izuzetak je bila jedinka OS 7, kod koje su reznice tretirane hormonskom otopinom IBA koncentracije $500 \mathrm{ppm}$ u trajanju od $10 \mathrm{~s}$ pozitivno reagirale povećanjem postotka zakorijenjenosti.

Što se tiče broja korijenskih žila, može se uočiti (slika 12) da je tretiranje baze reznica hormonskim otopinama neutralno ili negativno utjecalo na razvijenost korijena. Međutim, kod genotipova OS 4, OS 7, OS 9 i OS 10 tretiranje je hormonom ipak pozitivno djelovalo na razvoj većega broja korijenskih žila. Ipak, ne smije se zaboraviti da je tretiranje hormonom negativno djelovalo na uspjeh zakorjenjivanja reznica kod svih navedenih genotipova, izuzev OS 7 (v. slika 11). Zbog toga se tretiranje hormonskim otopinama ne može preporučiti kao pozitivan čimbenik koji povećava kvalitetu korijena reznica uzetih u kasnojesenskom razdoblju (osim kod genotipa OS 7).

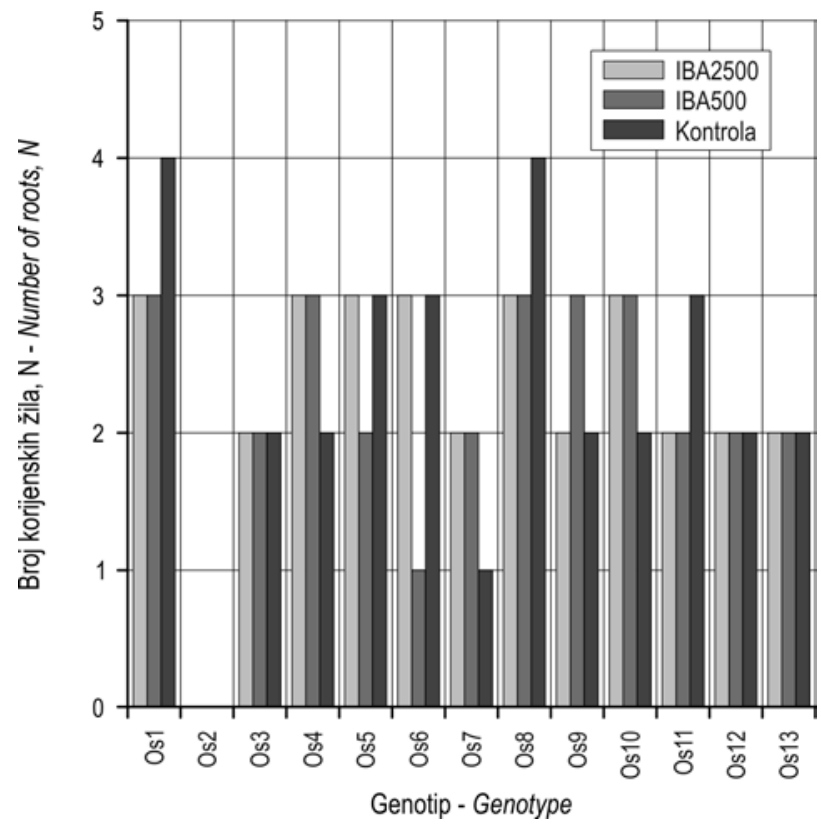

Slika 12. Usporedba prosječnoga broja korijenskih žila po genotipovima s obzirom na tretiranja i na kontrolu

Fig. 12 Mean number of roots per cutting due to various genotypes and hormonal treatments
Iz slike 13 razvidno je da je tretiranje hormonom IBA pozitivno djelovalo na razvoj korijena (prosječnu duljinu najdulje korijenske žile) samo kod manjega broja istraživanih genotipova (značajnije kod OS 4 i OS 5, a vrlo malo kod OS 7, OS 8, OS 9 i OS 10). Kod većine genotipova hormonski je tretman reznica djelovao neutralno ili čak negativno na razvoj korijena kod reznica.

U konačnici dobiveni rezultati pokazuju da je hormonski tretman preporučljiv samo za genotip OS 7, jer je samo kod te jedinke tretiranje baze reznica hormonom IBA pozitivno djelovalo na uspješnost zakorjenjivanja i na kvalitativne parametre razvijenosti korijena. Za sve ostale istraživane genotipove buduće tretmane reznica u ovom istraživanju primijenjenim hormonskim otopinama treba izbjegavati, barem što se tiče reznica koje se uzimaju u kasnojesenskom razdoblju.

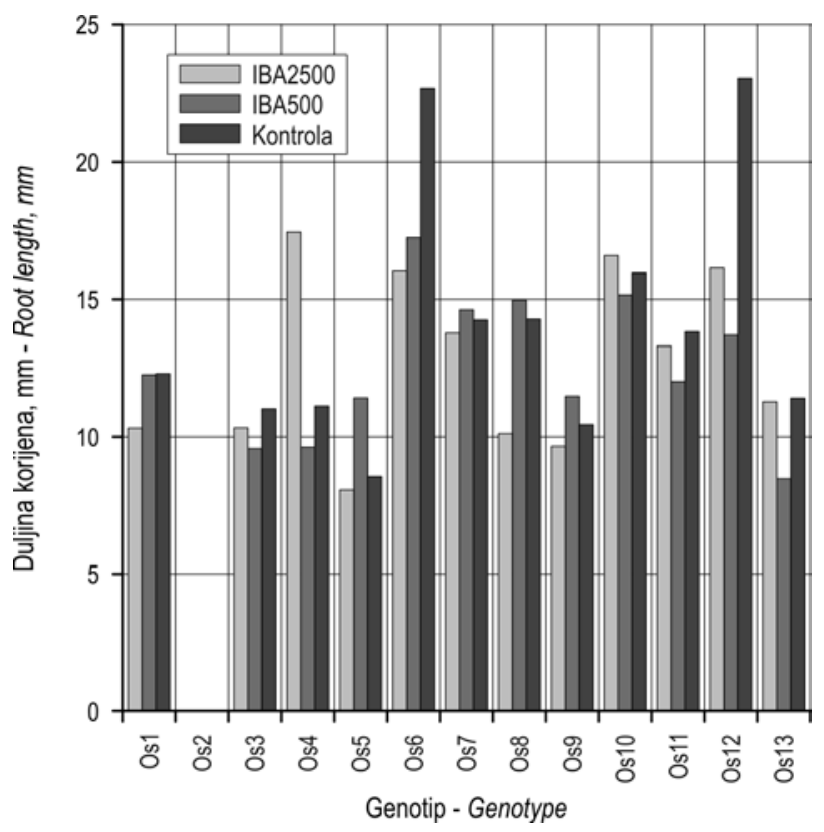

Slika 13. Usporedba prosječne duljine najdulje korijenske žile po genotipovima s obzirom na tretmane i na kontrolu

Fig. 13 Mean length of root per cutting due to various genotypes and hormonal treatments

\section{Rasprava - Discussion}

Na uspjeh kloniranja starijih ( $>5$ godina) stabala obične smreke klasičnom metodom - zakorjenjivanjem reznica utječu brojni biotski i abiotski čimbenici. Među najvažnijim su dob matičnoga stabla, fiziološki status matičnoga stabla, položaj reznica u krošnji matičnoga stabla, razdoblje uzimanja reznica, tretman reznica prije pikiranja, supstrat za piki- 
ranje, tretman reznica nakon pikiranja i dr. Mnogi su autori istraživali utjecaj tih i drugih čimbenika na uspjeh zakorjenjivanja reznica obične smreke. Nažalost, autori su prikazali vrlo raznolike rezultate i dali raznovrsne preporuke za povećanja uspješnosti kloniranja tom metodom. Stoga je odlučeno vlastitim istraživanjima pokušati utvrditi optimalnu tehnologiju kloniranja starijih selektiranih plus stabala obične smreke (u dobi od 10 do 12 godina).

U ovom su radu prikazani rezultati istraživanja dvaju eksperimenata kojima se pokušalo utvrditi: optimalan položaj reznica u krošnji matičnoga stabla; učinkovitost hormonskoga tretiranja reznica prije pikiranja na zakorjenjivanje i kvaliteta stvorenoga korijena; postojanje međugenotipskih razlika u zakorjenjivanju reznica; optimalno razdoblje za uzimanje odrvenjelih reznica.

Većina se relevantnih autora složila da se najuspješnije zakorjenjuju reznice obične smreke uzete iz donjih pršljenova krošnje, osobito kod starijih matičnih stabala (Jurásek i Martincová 2004, Roulund 1975, Hannerz i dr. 1999, prema Nikkanenu i dr. 2012). Rezultati ovoga rada potvrđuju navedena istraživanja jer su se odrvenjele reznice uzete iz donje trećine krošanja najbolje zakorijenile $(50 \%$ netretiranih kontrolnih reznica, u usporedbi s $40 \%$ kontrolnih reznica iz srednje i samo $20 \%$ zakorijenjenih kontrolnih reznica iz gornje trećine krošnje). Ipak, rezultati drugoga eksperimenta pokazali su i izrazite genotipske razlike $\mathrm{u}$ uspjehu zakorjenjivanja reznica uzetih iz donje etaže (postotak zakorjenjivanja kretao se od $0 \%$ do $100 \%$, ovisno o genotipu s kojega su uzete reznice). Može se pretpostaviti da je fiziološki status (npr. prehranjenost, kompeticija i dr.) matične biljke u trenutku uzimanja reznica imao vrlo važno značenje za uspješnost zakorjenjivanja reznica, a moguće je i da su genetski uvjetovane razlike među matičnim stablima dovele do ovakvih rezultata. U okviru ovoga istraživanja nije bilo moguće odrediti koja je od navedenih pretpostavki točna.

Različiti su autori iznijeli kontradiktorne rezultate o utjecaju tretiranja reznica prije pikiranja raznovrsnim tretmanima hormonskih otopina. Tako su o pozitivnim efektima hormona na zakorjenjivanje reznica obične smreke pisali Al-Kinany (1981), Međedović i Ferhatović (2003), Ma i dr. (2011) i OuYang i dr. (2014). Neki su autori naveli kako se reznice obične smreke sasvim dobro zakorjenjuju bez hormonskoga tretmana (Wühlisch 1984, Jurásek i Martincová 2004). Naposljetku, neki su autori izvijestili da je hormonski tretman imao negativan utjecaj na zakorjenjivanje reznica ove vrste (Farrar 1939, Giro- uard 1973, Dirr i Heuser 2006, Teivonen 2010, prema Nikkanenu i dr. 2012). Rezultati ovoga rada samo su potvrdili kontradiktornost ostalih istraživanja ove tematike jer su rezultati prvoga eksperimenta (odrvenjele reznice uzete $\mathrm{u}$ ranoproljetnom razdoblju) potvrdili pozitivne efekte specifičnih hormonskih otopina i specifičnoga vremena trajanja tretiranja, dok su rezultati drugoga eksperimenta (odrvenjele reznice uzete $\mathrm{u}$ kasnojesenskom razdoblju) potvrdili uglavnom negativne efekte hormonskih tretmana na uspjeh zakorjenjivanja reznica (pozitivan je efekt dobiven samo kod jednoga genotipa). Je li glavni razlog takvih kontradiktornih rezultata razlika u razdoblju uzimanja reznica između dvaju eksperimenata ili uzrok treba tražiti $\mathrm{u}$ različitom uzorku matičnih biljaka, ostaje otvoreno pitanje.

U svakom slučaju, u oba je eksperimenta dokazano da se obične smreke u dobi od desetak godina u prosjeku mogu relativno uspješno (prosječno $50 \%$-tni uspjeh) klonirati metodom zakorjenjivanja odrvenjelih reznica uzetih iz donje trećine krošanja, neovisno o tome jesu li uzete $\mathrm{u}$ kasnu jesen ili rano proljeće, i to bez ikakva tretiranja. Postotak zakorijenjenih reznica i kvaliteta novostvorenoga korijena mogu se poboljšati jeftinim, ali čini se učinkovitim tretiranjem baze reznica destiliranom vodom $u$ trajanju od 2 sata. Međutim, rezultati pokazuju da bi se tretiranjem baze odrvenjelih reznica uzetih $\mathrm{u}$ rano proljeće hormonskom otopinom IBA koncentracije $500 \mathrm{ppm}$ u trajanju od $10 \mathrm{~s}$ postotak uspješnoga zakorjenjivanja mogao značajno povećati (u prosjeku do $80 \%$-tne zakorijenjenosti).

\section{Zaključci - Conclusions}

$\mathrm{Na}$ temelju provedenih istraživanja i dobivenih rezultata mogu se donijeti ovi zaključci:

$\Rightarrow$ Obična smreka u dobi od 10 godina može se relativno uspješno klonirati metodom zakorjenjivanja reznica, i to odrvenjelim reznicama (jednogodišnjim postranim i vršnim izbojcima), uzetim iz donje trećine krošnje $u$ kasnu jesen ili $u$ rano proljeće, bez ikakva tretiranja prije pikiranja. Postotak zakorjenjivanja takvih reznica u prosjeku je $50 \%$, ali se može kretati od $0 \%$ do $100 \%$, ovisno o genotipu.

$\Rightarrow$ Postotak zakorjenjivanja reznica opada s obzirom na porast visine iz koje su uzete $u$ krošnji matičnoga stabla (niži dijelovi krošnje - veći postotak zakorjenjivanja reznica).

$\Rightarrow$ Učinkovit je način za povećanje postotka zakorjenjivanja odrvenjelih reznica (iz svih dijelova krošnje) i za kvalitetu novostvorenoga korijena 
tretiranje baze reznica destiliranom vodom $\mathrm{u}$ trajanju od dva sata prije pikiranja u supstrat.

$\Rightarrow$ Hormonsko tretiranje baze prije pikiranja može značajno povećati postotak zakorjenjivanja odrvenjelih reznica i kvalitativna svojstva novostvorenoga korijena, ali samo u slučaju kada su reznice uzete s matičnih stabala $\mathrm{u}$ rano proljeće (to vrijedi za reznice uzete iz donje i srednje trećine krošnje). Od svih istraživanih kombinacija hormonskih tretmana najboljim se pokazao tretman otopinom IBA koncentracije 500 ppm u trajanju od 10 sekundi.

$\Rightarrow$ Efekt hormonskoga tretiranja baze odrvenjelih reznica uzetih s matičnih stabala u kasnu jesen bio je negativan kod velike većine genotipova.

\section{Literatura - References}

Al-Kinany, A., 1981: Effect of auxins on root formation in the vegetative propagation of Populus alba, Populus tremula, Picea abies and Juniperus communis. Indian Forester, 107: 537-550. https://doi.org/10.36808/if/1981/ v107i9/11072

Bogdan, S., I. Čehulić, M. Ivanković, 2017: Začetak oplemenjivanja božićnih drvaca u Hrvatskoj. Nova mehanizacija šumarstva, 38: 91-96.

Clair, J. S., J. Kleinschmit, J. Svolba, 1985: Juvenility and serial vegetative propagation of Norway spruce clones (Picea abies Karst). Silvae Genetica, 34: 42-48.
Dekker-Robertson, D. L., J. Kleinschmit et al., 1991: Serial propagation in Norway spruce (Picea abies /L./ Karst.): results from later propagation cycles. Silvae Genetica, 40: 202-214.

Jurásek, A., J. Martincová, 2004: Possibilities of influencing the rooting quality of Norway spruce (Picea abies / L./ Karst.) cuttings. Journal of Forest Science, 50(10): 464-477. https://doi.org/10.17221/4642-JFS

Ma, J., S. An, L. Wang et al., 2011: Effects of different growth regulators on cutting and rooting abilities of Picea abies. Journal of Northwest Forestry University, 6: 18.

Međedović, S., Dž. Merhatović, 2003: Klonska proizvodnja sadnica drveća i grmlja. Bemust, Sarajevo, 216 str.

Nikkanen T., S. Heiska, T. Aronen, 2012: New ornamental conifers for harsh northern conditions through cutting propagation of special forms of Norway spruce. In: Y. S. Park and J. M. Bonga (eds), Proceedings of the IUFRO Working Party 2.09 .02 conference on »Integrating vegetative propagation, biotechnologies and genetic improvement for tree production and sustainable forest management«, June 25-28, 2012, Brno, Czech Republic.

OuYang, F., J. Wang, Y. Li, 2014: Effects of cutting size and exogenous hormone treatment on rooting of shoot cuttings in Norway spruce (Picea abies /L./ Karst.). New Forests, 46(1): 91-105. https://doi.org/10.1007/s11056-014-9449-1

Toogood, A. (ed.) 1999: The Royal Horticultural Society. Propagating plants, Dorling Kindersley, London, 70-91.

Wühlisch, G. von, 1984: Propagation of Norway Spruce cuttings free of topophysis and cyclophysis effects. Silvae Genetica, 33: 215.

\section{Abstract}

\section{Influence of Hormonal Treatments on Rooting of Norway Spruce (Picea Abies /L./ Karsten) Hardwood Cuttings}

By selecting plus trees in a base population, a breeding process of Norway spruce as Christmas trees was initiated in Croatia. The next stage of the process is the optimization of the cloning procedure of selected plus trees for the mass production of their reproductive material (seedlings). The assumption is that qualitative reproductive material exhibiting stability of targeted phenotypic traits will be created in such a way.

The main aim of the research was to determine the success of various hormonal treatments on rotting of hardwood cuttings of older Norway spruce trees (10-12 years). Two experiments were carried out. In the first, 270 cuttings were cut off in early spring from each of the three crown levels (upper, middle and lower third of a crown), on a sample of 10 trees. The cuttings from each level were treated with 24 different treatments (dipped in IBA and NAA hormone solutions of 250, 500, 2500 and $5000 \mathrm{ppm}$ for 10s, $1 \mathrm{~h}$ and $2 \mathrm{~h}$ ). In addition to these treatments, 10 cuttings from each crown level were treated with a commercial hormone product named Clonex (a gel). Additional 10 cuttings were treated with distilled water for $2 \mathrm{~h}$ and the remaining 10 were not treated. The last two groups of cuttings served as a control of the success of the analyzed hormonal treatments. Another study was conducted on 80 cuttings cut off in late fall from the lower third of a crown of the 13 selected plus trees. Thirty cuttings were treated for 10s with: (i) $2500 \mathrm{ppm}$ IBA solution, and (ii) $500 \mathrm{ppm}$ IBA solution. The remaining 20 cuttings served as the control. Afterwards, the cuttings were placed in containers filled 
with peat, sand and perlite substrate. The rooting success, the number of roots per cutting, and the length of the longest developed root were determined later in October.

The results showed that, on average, spruce trees at the age of 10+ years could be relatively successfully cloned (50\% rooted cuttings on average) by rooting hardwood cuttings taken in late autumn or early spring from the lower third of a tree crown, without any treatment. The percentage of rooted cuttings and the quality of newly created roots can be improved at low cost and high effectiveness by treating cuttings with distilled water for 2 hours. However, the results indicated that by treating the base of cuttings taken in early spring with a hormonal solution of $500 \mathrm{ppm}$ IBA for 10s, the percentage of successful rooting could be significantly increased (up to an average of $80 \%$ rooting). Hardwood cuttings taken from the lower third of crowns were most successfully rooted, even without any treatment (50\% control cuttings, compared to $40 \%$ control cuttings from the middle and $20 \%$ rooted cuttings from the top third of crowns). The results also indicated marked individual differences in the success of rooting of cuttings taken from the lower parts of a crown (percentage of rooting ranged from $0 \%$ to $100 \%$ ).

Keywords: Christmas trees, breeding, plus trees, cloning, genotypes, IBA, NAA

Primljeno (Received): 14. 9. 2019.

Prihvaćeno (Accepted): 05. 10. 2019.
Adrese autorâ - Authors' addresses:

Nikola Bursać, mag. ing. silv.

Šumarski fakultet Sveučilišta u Zagrebu

Svetošimunska 25

10000 Zagreb

HRVATSKA

Ivica Čehulić, dipl. ing. šum.

e-pošta: ivicac@sumins.hr

Dr. sc. Mladen Ivanković

e-pošta:mladeni@sumins.hr

Hrvatski šumarski institut

Cvjetno naselje 41

10450 Jastrebarsko

HRVATSKA

Prof. dr. sc. Saša Bogdan*

e-pošta: sbogdan@sumfak.unizg.hr

Šumarski fakultet Sveučilišta u Zagrebu

Svetošimunska 25

10000 Zagreb

HRVATSKA

* Glavni autor - Corresponding author 
